\title{
Using Stem Cells in Skin Regeneration: Possibilities and Reality
}

\author{
Mariana Teixeira Cerqueira, ${ }^{1,2}$ Alexandra Pinto Marques, ${ }^{1,2}$ and Rui Luís Reis ${ }^{1,2}$
}

Tissue-engineered skin has a long history of clinical applications, yet current treatments are not capable of completely regenerating normal, uninjured skin. Nonetheless, the field has experienced a tremendous development in the past 10 years, encountering the summit of tissue engineering (TE) and the arising of stem cell research. Since then, unique features of these cells such as self-renewal capacity, multi-lineage differentiation potential, and wound healing properties have been highlighted. However, a realistic perspective of their outcome in skin regenerative medicine applications is still absent. This review intends to discuss the directions that adult and embryonic stem cells (ESCs) can take, strengthening the skin regeneration field. Distinctively, a critical overview of stem cells' differentiation potential onto skin main lineages, along with a highlight of their participation in wound healing mechanisms, is herein provided. We aim to compile and review significant work to allow a better understanding of the best skin TE approaches, enabling the embodiment of the materialization of a new era in skin regeneration to come, with a conscious overview of the current limitations.

\section{Introduction}

Sin Regeneration is an important area of research in Sthe tissue engineering (TE) field, especially for massive skin loss cases, where current treatments are yet not capable of inducing permanent satisfying skin regeneration [1]. To achieve an effective healing, skin TE products must attach well to the wound bed, be supported by new vasculature, integrate with the surrounding host tissues, be nonimmunogenic, and be capable of self regeneration with minimum scar tissue, with reduced patient pain and discomfort, and yet importantly, manufactured with a good cost-benefit ratio [2].

Skin TE went through a difficult time early in the 20th century, but with the commercial success that several products have achieved, it has entered a new area of enterprise [3]. Skin analogues have the longest history of commercialization, and the clinical applicability of cellular skin substitutes such as Apligraf ${ }^{\circledR}$ and Orcel $^{\circledR}$ is significant [4]. However, among the currently commercialized ones, the major hurdles encountered are high production costs along with the failure of keratinocyte performance and delayed vascularization. Angiogenesis, relying in most of the cases upon patient's wound bed condition, is in fact a critical aspect for the success of skin analogues, achieved so far in substitutes with 0.4-mm maximum thickness [5]. Although deficient, there has been an emergence of skin TE models involving the generation, prior to implantation, of a microvascular network that anastomose with the patient's blood vessels and consequently lead to a faster vascularization [610]. Commercial skin models have also been considered far from what would be suitable in terms of immunogenicity, as those containing nonautologous adult cells can induce immune rejection [11]. It is now clear that another obstacle in the long-term function of skin equivalents is limited by the terminal differentiation of the grafted keratinocytes due to prolonged in vitro culture that reduces the number of highly proliferative units (holoclones) [12]. Thus, in order to meet the need for maintaining keratinocytes in an early differentiation state, the revolutionary approach in skin TE comprises the use of stem cells, guarantying also an unlimited source of biological material, crucial for large full-thickness skin defects.

This review aims to present the rationale for the use of stem cells in skin regeneration, showing the current drawbacks and the different angles whereby these cells can contribute with their unique features.

\section{Stem Cells Contribution to Skin Relevant Lineages}

Distinct sources of stem cells (SCs), comprising both adult and embryonic stem cells (ESCs), have unique intrinsic features that might represent an effective way to meet the

\footnotetext{
${ }^{1} 3 B^{\prime}$ s Research Group-Biomaterials, Biodegradables, and Biomimetics, University of Minho, Headquarters of the European Institute of Excellence on Tissue Engineering and Regenerative Medicine, Guimarães, Portugal.

${ }^{2}$ ICVS-3B's_PT Government Associate Laboratory, Braga/Guimarães, Portugal.
} 
challenge of skin replacement and its current major drawbacks as presented above. This is due to foremost characteristics such as the potential to provide an unlimited source of donor material for grafting along with the ability to switch into any cell phenotype in vitro, such as endothelial and epidermal. In fact, improved vascularization is required, generally to allow faster inosculation and specifically to promote healing of chronic skin wounds. Moreover, epidermal analogues created from epidermal stem cells or stemderived epidermal precursors have the advantage, in relation to fully differentiated keratinocytes in specific clinical settings, of being available in a shorter time due to the cells' higher proliferation capacity and at an earlier differentiation stage, which is expected to contribute to a higher quality healing and to skin regeneration rather than repair.

Overall stem cells characteristics have been extensively reviewed [13-17]. This section aims to provide a critical and organized perspective of the works that have been carried out with both adult and ESCs, which justify the valuable potential of SCs from different origins to be further explored in skin TE purposes.

\section{Stem cell origins}

Mesenchymal stem cells (MSCs), a considerable part of adult stem cells, integrate several mammalian tissues and are natural key players in tissue regeneration. Although their primary function is homeostasis maintenance, they also seem to still express pluripotency markers, having the valuable potential to switch into different cell types other than into cell connective tissue lineages $[18,19]$ and represent a compatible source to allogenic transplantation due to their immunomodulatory and immunosuppressive features [20]. In addition to most well-described bone marrow MSCs [21], other relevant MSCs such as human adipose-derived stem cells (hASCs) [22], due to their abundance, ready accessibility, and easy expansion in vitro; human amniotic fluid stem cells (hAFSCs), which represent an intermediate stage between adult and embryonic SCs (ESCs) [23,24]; and umbilical cord blood (UCB), with its easy accessibility [25] and primal nature [26], are highly attractive for the skin regeneration field. Skin also shelters dermal MSCs, which have high proliferative capacity and the ability to differentiate into mesodermal lineages [27]. Their plasticity has been reinforced by the presence of pluripotency-associated markers $[19,28]$.

However, the nature of MSCs is not fully clear; these cells are closely associated with perivascular niches [29] and coexpress many markers in common with pericytes in the microvasculature and adventitial fibroblast-like cells that surround the larger blood vessels $[30,31,32]$, even though it remains possible that some MSCs originate in other cell subsets [33]. Furthermore, the dual origin of MSCs in a single tissue is suggested by the pericytes' capacity to differentiate into cells of mesenchymal origin, alongside with other MSCs of a nonpericytic origin [31]. In line with this, several studies revealed that human dermal fibroblasts, $(\mathrm{hDFb})$ are difficult to distinguish from dermal MSCs, due to $\mathrm{hDFb}$ unexpected plasticity and immunoregulatory features [34,35]. Furthermore, it was recently reported that $\mathrm{hDFb}$ can generate, from a single cell (muse cell), others that form characteristic cell clusters expressing a set of markers related with pluripotency, raising the possibility to explore this feature benefiting from $\mathrm{hDFb}$ incapacity to form teratomas in vivo. Hence, despite the attempts that have been outlined for clarification [36], the limit to distinguish human dermal MSCs from $\mathrm{hDFb}$ ability is vague. For skin regeneration, the most important aspect relies on taking advantage of the classical features of fibroblasts and exploring the newly described qualities to achieve an improved skin model.

Besides the previously referenced skin MSCs, skin tissue also contains the skin resident naïve cells, representing a valuable cell source for skin TE. Their main niches include the apex of rete ridges [37] and the bulge of hair follicles [38] in the epidermis, and also the papillary dermis in the dermal compartment [39]. Epidermal stem cells (EpSCs) have a strong capacity for self-renewal and originate rapidly proliferating daughter cells - transient amplifying cells (TA) that undergo several cell divisions before differentiating [40]. Despite the effort undertaken to characterize EpSCs and to assemble techniques that would allow better population purification [41-44], specific markers of EpSCs are still questionable. While $\beta 1$-integrin [42], the hemidesmosomal a6-integrin [44], and LGR5/LGR6 [45,46] are possible markers for stem cells in the hair follicle niche, early keratin markers such as K19, K14, and K15 are also shared with TA $[47,48]$, though the distinct behavior of EpSCs and TA in vitro and in vivo have led to further define the retention of DNA label in vivo, and the in vitro clonal growth, as part of EpSCs' characterization criteria [49]. Within the dermis, hairfollicle sheath stem cells [50] and skin-derived precursors (SKPs) [51] have been recognized. While hair-follicle dermal sheath cells can be explored in a therapeutic context as an accessible option for improving the healing outcome of dermal or full skin equivalents, yet maintaining their role in the regeneration of hair follicles [52], SKPs, by sharing many characteristics with embryonic neural crest stem cells-including neural crest-like differentiation potential, in vitro and in vivo [39] — might be explored to promote the regeneration of skin nervous appendages. Nevertheless, optimization of protocols for human SKP isolation and differentiation into potentially clinically useful cell subtypes remains a challenging prerequisite to reach clinical translation [53].

ESCs are naturally the favorite candidates for regenerative medicine and TE due to their immortality, self-renewal ad infinitum, and highly versatile ability to differentiate into components of all embryonic germ layers (Fig. 1) [54], which might promote the use of these cells over adult stem cells. However, accurate and well-established differentiation techniques will be essential to the use of ESC-derived cells in future applications, namely in epidermis replacement $[9,55-$ 61] and for improving vascularization [61-66]. Further expectations rely on the development of efficient protocols to obtain melanocytes and promote regeneration of skin appendages, which would undoubtedly improve the overall functionality of skin substitutes [67].

\section{Stem cells epidermal commitment potential}

The commitment and differentiation of stem cells into epidermal/epithelial cells involve complex signaling pathways and multiple stimuli that occur naturally in an adequate microenvironment, but which have not been fully understood. 

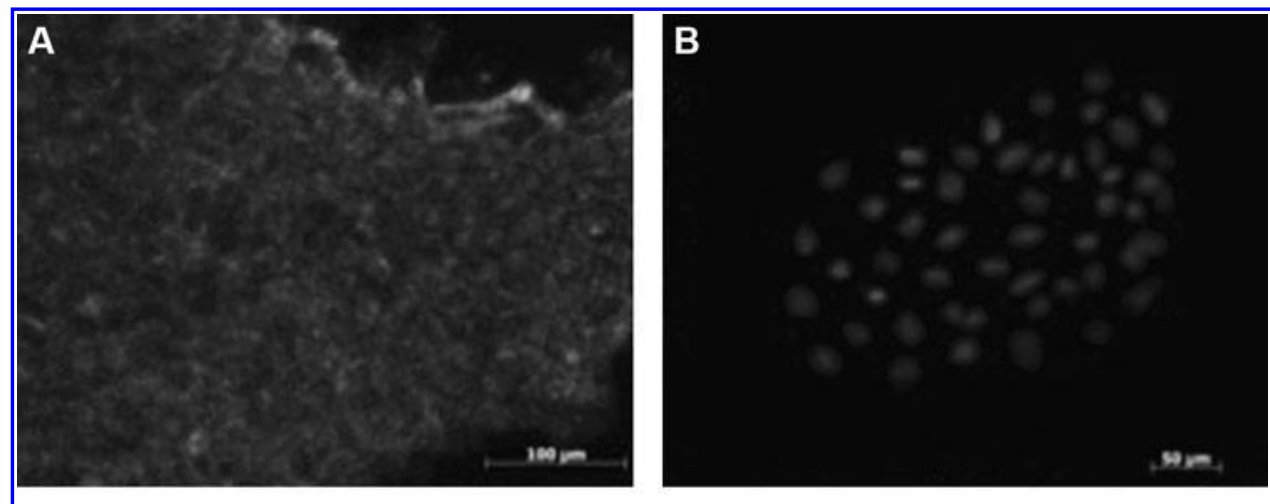

FIG. 1. KCL-002 human embryonic stem cell (hESC) cell line stained for plur-

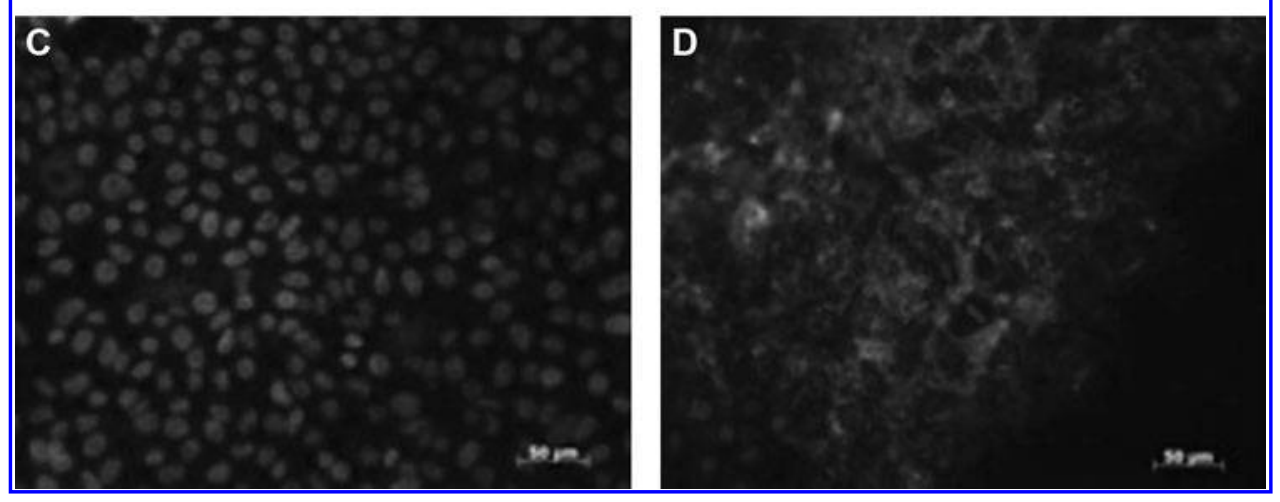
ipotency markers SSEA-4 (A), Sox2 (B), Oct4 (C), and TRA160 and hoechst (D) by immunocytochemistry.

Nevertheless, an effort to disclose this phenomenon has been explored in vitro $[55,56,58-60,68-74]$ using distinct strategies, mostly focusing on MSC and ESC differentiation.

MSCs. In specific case of MSC differentiation toward keratinocytes, new methods has been explored for several stem cells such as bone marrow mesenchymal stem cells (BM-MSCs) [69,72], umbilical cord blood stem cells (UCBSCs) [68,71], and hASCs [73] and are mainly based on cytokine cocktails $[56,60,68-70]$, as well as on keratinocyte paracrine signaling $[69,71,72,75]$ (Table 1$)$.

BM-MSCs were proven to give rise to epithelial-like cells, forming cobblestone pattern colonies and expressing both cytokeratin 18/19-when cultured with a growth factors cocktail that includes epidermal growth factor (EGF), keratinocyte growth factor (KGF), hepatocyte growth factor (HGF) - and insulin growth factor 2 (IGF-2) [72]. A higher expression of epithelial markers on the cells of clusters in the inner zone was observed, suggesting that most probably only these cells suffer differentiation due to the synergistic action of the growth factors and the stronger paracrine signaling, as described in other works [76,77]. Epidermallike cells, expressing the early keratinocyte markers p63, cytokeratin 19, and $\beta 1$-integrin and the late marker pancytokeratin were also generated from BM-MSCs [69]. In this work, cells seeded at higher densities demonstrated a more pronounced expression of those markers, implying that cellcell contact, as expected, must be also considered as an important parameter to differentiate BM-MSCs into epidermal lineage cells. Although both studies [69,72] employed growth factors within the same concentration range, the role of each of these in epithelial and epidermal differentiation is yet undefined. Moreover, an analysis of stem cell markers, still lacking, would provide further information regarding differentiation efficiency of each strategy.
Findings with UCBSCs have underlined the potential of paracrine adult cell signaling and its effects on directing stem cell phenotype [71]. In this particular study, UCBSCs were co-cultured with adult keratinocytes on fibrin glue gel with encapsulated fibroblasts in vitro, and differentiation of UCBSCs into epidermal cells was detected. In addition, these results demonstrate that using this methodology the required initial number of both primary and stem cells is lower, as a mixture of both cell types was used, which might serve as a starting material for isolation and expansion of cells for transplantation in patients with large skin defects. A more recent work [68] also using hUCB as biological source of stem cells, investigated the use of a specific medium composed of a mixture of a basal medium and another that is normally used to expand keratinocytes, called the saigonese culture [68], to lead those cells into the epidermal lineage. After 7 days of culture, p63 and keratin1/10 positive cells were detected, meeting the postulated multipotential of UCBSCs. Nonetheless, issues such as isolation techniques employed, which result in low yields of the UCBSCs, and percentage of differentiated cells might be among the main concerns in the perspective of the clinical application of these cells.

A single in vitro study with hASCs showed that under the effect of all-trans retinoic acid (ATRA), cytokeratin 18 positive cells are generated, indicating hASCs' epithelial differentiation potential [73]. However, ATRA reduces cell viability in a concentration-dependent manner, and without the expression of typical keratinocytes markers, it is still insufficient to consider those cells for skin TE purposes.

All of these in vitro strategies have shown signal stem cells to change their gene expression patterns and transdifferentiate into epidermal/epithelial-like cells. However, in vitro assays to demonstrate this stratification capacity, as well as 
Table 1. Epidermal Commitment of Different Sources of Stem Cells

\begin{tabular}{|c|c|c|c|c|c|c|}
\hline $\begin{array}{l}\text { Tissue } \\
\text { source }\end{array}$ & $\begin{array}{l}\text { Cell } \\
\text { type }\end{array}$ & $\begin{array}{l}\text { Stem cell } \\
\text { plasticity }\end{array}$ & Strategy & Obtained Cells & Epidermal features & References \\
\hline \multirow[t]{2}{*}{$\begin{array}{l}\text { Bone } \\
\text { marrow }\end{array}$} & MSCs & Multipotent & $\begin{array}{l}\text { Growth factors cocktail: } \\
\text { EGF, KGF, HGF and } \\
\text { IGF-2 }\end{array}$ & Epithelial-like cells & $\begin{array}{l}\text { Cobblestone pattern } \\
\text { clusters } \\
\text { Cytokeratin 18/19 }\end{array}$ & [72] \\
\hline & & & $\begin{array}{l}\text { Growth factors cocktail: } \\
\text { EGF, insulin, FGF, } \\
\text { retinoic acid and } \\
\mathrm{CaCl}_{2}\end{array}$ & Epidermal-like cells & $\begin{array}{l}\text { p63, cytokeratin 19, } \\
\beta 1 \text {-integrin, } \\
\text { pancytokeratin }\end{array}$ & [69] \\
\hline \multirow[t]{2}{*}{$\begin{array}{l}\text { Umbilical } \\
\text { cord } \\
\text { blood }\end{array}$} & MSCs & Multipotent & $\begin{array}{l}\text { Co-culture with adult } \\
\text { keratinocytes in fibrin } \\
\text { glue gel }\end{array}$ & $\begin{array}{l}\text { Keratin in all cells of } \\
\text { layered cultured } \\
\text { epidermis }\end{array}$ & Keratin-positive cells & [71] \\
\hline & & & $\begin{array}{l}\text { Mixture of primary } \\
\text { culture medium and } \\
\text { keratinocyte serum- } \\
\text { free medium }\end{array}$ & keratinocytes & p63 and Keratin1-10 & [68] \\
\hline $\begin{array}{c}\text { Adipose } \\
\text { tissue }\end{array}$ & MSCs & Multipotent & $\begin{array}{l}\text { ATRA in culture } \\
\text { medium }\end{array}$ & Epithelial-like cells & Cytokeratin 18 & [73] \\
\hline \multirow[t]{5}{*}{ Embryo } & hESCs & Pluripotent & Nodules in scid mice & keratinocytes & $\begin{array}{l}\text { p63, basonuclin, keratin } \\
14 \text { and involucrin }\end{array}$ & [74] \\
\hline & & & $\begin{array}{l}\text { Embryoid bodies/ } \\
\text { nodules in scid mice }\end{array}$ & keratinocytes & $\begin{array}{c}\text { p63, basonuclin, keratin } \\
14,5 \text { and involucrin }\end{array}$ & [80] \\
\hline & & & $\begin{array}{l}\text { BMP4 and PA6 stromal } \\
\text { cells }\end{array}$ & Keratinocyte precursors & Cytokeratin 18/14 & {$[9,58,59,75,81]$} \\
\hline & & & $\begin{array}{l}\text { Retinoic acid and BMP4 } \\
\text { (in both embryoid } \\
\text { bodies and 2D } \\
\text { culture) }\end{array}$ & Keratinocytes & $\begin{array}{l}\text { Cytokeratin } 14 \\
\text { pluristratified } \\
\text { epidermis formation }\end{array}$ & {$[56,60]$} \\
\hline & & & Ascorbic acid and BMP4 & Keratinocytes & $\begin{array}{l}\text { pluristratified epidermis } \\
\text { in vitro and grafting } \\
\text { in vivo }\end{array}$ & [57] \\
\hline
\end{tabular}

Summary of the strategies employed to induce stem cells differentiation indicating the strategies employed and the main characteristics of the obtained cells.

ATRA, all-trans retinoic acid; BMP4, bone morphogenetic protein 4; EGF, epidermal growth factor; FGF, fibroblast growth factor; hESCs, human embryonic stem cells; HGF, hepatocyte growth factor; IGF, insulin growth factor; KGF, keratinocyte growth factor; MSCs, mesenchymal stem cells.

functional in vivo studies, are still lacking in most of the studies. Moreover, apart from a recent work that demonstrates that human umbilical cord lining epithelial cells are capable of generating a fully stratified epithelium [78], it is still necessary to verify whether the hMSC-derived cells have the same behavior as resident epidermal stem cells, notably in terms of multipotency and engagement in terminal differentiated/cornified cells to potentiate clinical application of stem cells in epidermal reconstruction.

ESCs. The possibility of human embryonic stem cells hESCs to differentiate towards the epidermal lineage has also been explored using distinctive strategies. Within embryoid bodies (EBs) or nodules produced in immunosuppressed mice $[74,79,80]$, hESCs were able to differentiate along epidermal lineage, yet had a low proliferative capacity. Moreover, this technique lacks in terms of differentiation accuracy; being based in spontaneous differentiation, other lineages are naturally present, which is limiting for regenerative medicine applications.

A strategy based on the recapitulation of ectodermal development in vitro was proposed by Aberdam et al. $[9,58,59,75,81]$. Bone morphogenetic protein 4 (BMP4) effect along with the contribution of mesenchymal inducers (PA6 stromal cells) on ESC cultures was explored to generate cytokeratin $18 / 14$ positive cells. The authors suggested this approach following the rationale of a coordinated development of the ectodermal and mesodermal layers during morphogenesis, leading the support and directing a number of biological functions including cell proliferation, migration, and differentiation by the reciprocal signaling of these two mutually dependent tissues [82]. This is consistent with the generation of keratinocytes from mouse ESCs seeded on matrix derived from human fibroblasts and exposed to BMP4 at different days of culture [83]. Knowing that epidermal and neural precursors are derived from the same neuroectodermal precursor [84], there was the need to clarify the successive development from ESCs to an ectodermal phase and the subsequent switching to epidermal precursors. For that, it was highlighted that the ectodermal commitment occurs through the activation of transcription factor $\Delta \mathrm{Np} 63$, which seemed to play a dual role in early steps of epidermal precursor formation after BMP4 administration, acting as an epidermal inducer and an inhibitor of neural precursor formation [85]. In addition, $\Delta \mathrm{Np} 63$ was demonstrated to be able to directly activate K14 promoter [86]. The importance of BMP4 in hESCs' differentiation pattern toward epidermal lineage, by blocking neural differentiation via Smad pathway [87] was also confirmed by obtaining a fairly pure keratinocyte population using retinoic acid along with BMP4, both in EBs and 2-dimensional hESC cultures (Fig. 2) [56]. The 


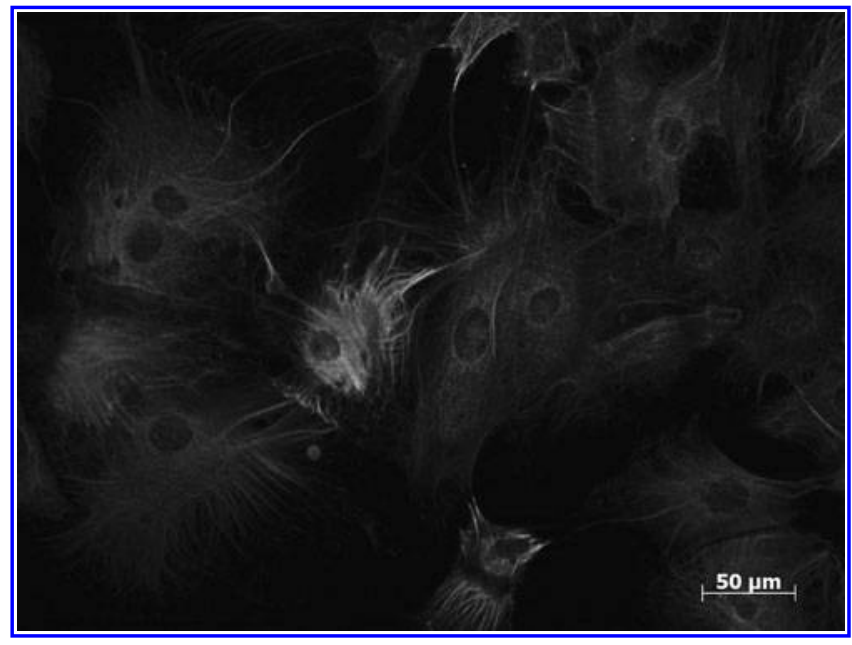

FIG. 2. Keratinocyte precursors derived from KCL-002 hESC cell line, co-expressing keratin 18 and keratin 14, after treatment with retinoic acid and bone morphogenetic protein 4 for 25 days in culture.

synergistic relation of the factors used softened the dilemma of neural versus epithelial specification among ectodermal precursors, giving rise to K14 positive cells. Moreover, the functional similarity of the generated keratinocytes to primary epithelium was demonstrated by showing that the obtained cells respond to microenvironment in a similar manner to adult keratinocytes [60]. Although some consistency has been demonstrated with the proposed strategies to obtain ESC-derived keratinocytes regarding comparable features with adult keratinocytes, at a protein level of expression and functionality, the reconstruction of a stratified epidermis is still lacking, with the exception of a study that used ascorbic acid and BMP4 for 40 days [57]. The authors claimed to mimic the long-term succession of biological steps that lead to epidermis formation during organogenesis generating functional basal keratinocytes with the ability to form a stratified epithelium that resembles normal human epidermis both in vitro and following grafting.

Co-cultures of stem cells with adult cells, by taking advantage of the signal cues provided by these, are another promising approach to drive stem cell fate into a specific desired phenotype. Mouse ESCs directly co-cultured with mice keratinocytes were directed into the epidermal pathway as they were shown to express epidermal related markers, such as keratin 14 and k19, among others [88]. Despite the high potential of these studies, as the signaling provided by adult cells might be the key for phenotype switching, additional refinement of this methodology is required. Furthermore, transposing this approach to human cells together with functional tests, along with proteomics analysis, urges further exploration of the whole success of the strategy.

In what concerns epidermal fate irrespective of the SCs origin, there is still a long way to be explored in order to generate significant knowledge regarding the differentiation mechanisms involved. Moreover, the need to decrease the differentiation time-span to envision the clinical application of stem-derived epidermal/epithelial cells is still a reality.

\section{Endothelial differentiation advances}

Like for any other vascularized tissue, endothelial and endothelial progenitor cells also play a major role in skin regeneration, as they are responsible for the vascularization of the newly formed tissue. Together with pericytes, they ensure a stable and organized vascular network that supplies the whole tissue [89].

Despite the different approaches that have been employed to drive both adult and ESCs towards the endothelial lineage (see Table 2), no standardized protocols exist for generating stem cell-derived vascular cells [90]. The administration, in variable concentrations, of the most studied angiogenic cytokine, vascular endothelial growth factor (VEGF), [61,6365,91-97] has been the most used route. However, distinct approaches such as co-cultures with other cells [98,99], SC exposure to mechanical stimulation [63,95-97], and other microenvironmental cues [100-103] also represent alternative attempts to accomplish this purpose.

The endothelial differentiation of hESCs has been predominantly achieved by spontaneous differentiation of EBs grown for 10 to 13 days, which closely recapitulate that of early in vivo embryogenesis $[61,65,66]$. Differentiated cells are then sorted for VE-cadherin/PECAM and cultured in VEGF-containing medium [61] or, alternatively, directly cultured in methylcellulose in a medium cocktail including ascorbic acid and insulin/transferring/selenium [66]. hESCs in monolayer were also led toward the endothelial phenotype after subculture in collagen 4 substrate and supplementation with VEGF [65]. More recently, a novel method without cell-sorting technique that consists of culturing the generated EBs using a differentiation medium with VEGF, BMP4, stem cell factor, interleukin 3 (IL), and IL6 was reported [64]. The obtained cells were capable of supporting subculture at least up to 10 passages without phenotypical depression, and more importantly, effective engraftment in vivo.

Like for the differentiation of ESCs into the epidermal lineage, some works that intended to shed some light on the signaling mechanisms that mediate development of early hemato-endothelial progenitors during human development have also demonstrated its usefulness as promising approaches to explore the endothelial differentiation of ESCs $[98,99]$. Those studies have generated hESC-derived cells with hematopoietic [98] and endothelial potential $[98,99]$ by co-culturing hESCs in inactivated BM stromal cells, though after selecting the generated CD34 ${ }^{+}$[99] and CD34 ${ }^{\text {bright }} \mathrm{CD} 31^{+} \mathrm{Flk} 1^{+}$[98] subpopulations.

Despite the discussions and attempts to clarify the potential of ESCs and the mechanisms involved in endothelial differentiation [62,90], the understanding of the role of secreted and cell-bound factors associated with stromal cells used to promote that switch is still in an early stage. Further investigation and advances regarding the hESC culture might also be relevant to progress toward the control of lineage-specific and in particular endothelial differentiation.

As mentioned above, the differentiation of adult SCs, namely BM-MSCs, UC-MSCs, hASCs, and hAFSCs, has been predominantly relying on the use of culture cocktails with distinct growth factors, but commonly including VEGF $[63,92,95-97]$. The variability of the results obtained, naturally arising from the numerous factors involved, 
Table 2. Outline of the Stem Cells' Differentiation Into Endothelial Lineage Showing the Central Strategies Used and Highlighting the Characteristics of the Derived Cells

\begin{tabular}{|c|c|c|c|c|c|}
\hline Tissue source & Cell type & Stem cell plasticity & Strategy & Endothelial features & References \\
\hline \multirow[t]{5}{*}{ Embryo } & \multirow[t]{5}{*}{ hESCs } & \multirow[t]{5}{*}{ Pluripotent } & $\begin{array}{l}\text { Embryoid bodies, sorting with } \\
\text { VE cadherin/PECAM and } \\
\text { VEGF culture }\end{array}$ & $\begin{array}{l}\text { PECAM-1, CD34, } \\
\text { VE-cadherin,Tie-2, Flk-1 } \\
\text { Cord formation in matrigel } \\
\text { In vivo vessel formation }\end{array}$ & {$[61]$} \\
\hline & & & $\begin{array}{l}\text { Embryoid bodies and culture in } \\
\text { methylcellulose, plus medium } \\
\text { containing ascorbic acid, } \\
\text { insulin/transferring/selenium }\end{array}$ & $\begin{array}{l}\text { PECAM-1, Flk-1, VE-cadherin } \\
\text { In vivo vessel formation }\end{array}$ & [66] \\
\hline & & & $\begin{array}{l}\text { Subculture in collagen } 4 \\
\text { substrate, supplemented with } \\
\text { VEGF }\end{array}$ & $\begin{array}{l}\text { CD34, 20VCAM1, PECAM-1, } \\
\text { VE-cadherin } \\
\text { In vivo vessel formation }\end{array}$ & {$[65]$} \\
\hline & & & $\begin{array}{l}\text { Coculture with murine S17 } \\
\text { stromal cells }\end{array}$ & $\begin{array}{l}\text { PECAM-1,vWF, DiI-Ac-LDL } \\
\text { uptake }\end{array}$ & [98] \\
\hline & & & $\begin{array}{l}\text { Spheres plus differentiation } \\
\text { medium with VEGF, BMP4, } \\
\text { stem cell factor,IL3 and IL6 }\end{array}$ & $\begin{array}{l}\text { vWF, CD34, VE-cadherin, } \\
\text { VEGF-receptor } 1 / 2 / 3 \\
\text { Dil-AcLDL uptake } \\
\text { Cord formation in matrigel }\end{array}$ & [64] \\
\hline \multirow[t]{3}{*}{ Bone marrow } & \multirow[t]{3}{*}{ MSCs } & \multirow[t]{3}{*}{ Multipotent } & $\begin{array}{l}\text { Growth factors cocktail, mainly } \\
\text { VEGF }\end{array}$ & $\begin{array}{l}\text { Flk-1, VE-cadherin, vWF, } \\
\text { DiI-Ac-LDL uptake } \\
\text { Cord formation in matrigel }\end{array}$ & {$[63]$} \\
\hline & & & $\begin{array}{l}\text { Culture in ECM secreted by } \\
\text { microvascular endothelial cells }\end{array}$ & PECAM & [106] \\
\hline & & & $\begin{array}{l}\text { 3D- structure of fibrinogen with } \\
\text { PEG derivatives }\end{array}$ & $\begin{array}{l}\text { High number of angiogenic } \\
\text { genes, including VEGF-A and } \\
\text { CD31 }\end{array}$ & [102] \\
\hline \multirow[t]{2}{*}{ Umbilical cord } & \multirow[t]{2}{*}{ MSCs } & \multirow[t]{2}{*}{ Multipotent } & $\begin{array}{l}\text { Growth factors cocktail, mainly } \\
\text { VEGF }\end{array}$ & $\begin{array}{l}\text { Flk-1, VE-cadherin, vWF, } \\
\text { DiI-Ac-LDL uptake } \\
\text { Cord formation in matrigel }\end{array}$ & {$[92]$} \\
\hline & & & VEGF, EGF, and hydrocortisone & $\begin{array}{l}\text { lk-1, Flt-1, VE-Cadherin, vWF, } \\
\text { VCAM-1, Tie-1 and Tie-2, } \\
\text { DiI-Ac-LDL uptake } \\
\text { Cord formation in matrigel }\end{array}$ & [97] \\
\hline \multirow[t]{3}{*}{ Adipose tissue } & \multirow[t]{2}{*}{ MSCs } & \multirow[t]{2}{*}{ Multipotent } & $\begin{array}{l}\text { ECGS medium together with } \\
\text { exposure to physiological } \\
\text { shear force }\end{array}$ & $\begin{array}{l}\text { PECAM-1,vWF, DiI-Ac-LDL } \\
\text { uptake } \\
\text { Cord formation in matrigel } \\
\text { In vivo validation }\end{array}$ & [95] \\
\hline & & & $\begin{array}{l}\text { N-(6-aminohexyl)-5-chloro-1- } \\
\text { naphthalenesulfonamide } \\
\text { Different concentrations of } \\
\text { VEGF and bFGF }\end{array}$ & $\begin{array}{l}\text { vWF, VE-Cadherin, cord } \\
\text { formation in matrigel }\end{array}$ & [94] \\
\hline & SVF & Multipotent & $\begin{array}{l}\text { CD34+ /CD13 + spontaneous } \\
\text { differentiation in } \\
\text { methylcellulose cultures }\end{array}$ & $\begin{array}{l}\text { CD31, vWF, cord formation in } \\
\text { matrigel, in vivo validation }\end{array}$ & [105] \\
\hline Amniotic-fluid & MSCs & Multipotent & EGM-2, shear force, hypoxia & $\begin{array}{l}\text { PECAM-1,vWF, DiI-Ac-LDL } \\
\text { Cord formation in matrigel }\end{array}$ & [96] \\
\hline
\end{tabular}

bFGF, basic fibroblast growth factor; BMP4, bone morphogenetic protein 4; DiI-Ac-LDL, DiI acetylated low-density lipoprotein; ECGS, endothelial cell growth supplement; ECM, extracellular matrix; EGF, epidermal growth factor; EGM-2, endothelial growth media-2; hESCs, human embryonic stem cells; IL3, interleukin 3; IL6, interleukin 6; MSCs, mesenchymal stem cells; PECAM, anti-human CD31; PEG, polyethylene glycol; SVF, stromal vascular fraction; VCAM1, vascular cell adhesion protein 1; VE, vascular endothelial; VEGF, vascular endothelial growth factor; vWF, von Willebrand factor.

nonetheless represents the difficulty in achieving relevant results as well as the long way still to go to establish reliable and clinically acceptable methods for obtaining endothelial cells from adult SCs. In fact, the concentration of VEGF, ranging from 5 to $100 \mathrm{ng} / \mathrm{mL}$ [104], constitutes a major drawback of these approaches and an impairment for scaling up.

Local environment, namely extracellular matrix (ECM)originated biochemical and mechanical signals, is known to directly influence MSC differentiation [101,100,102]. Me- chanical stress $[63,95,96]$ in particular was proven to promote the endothelial differentiation of adult SCs, as well as the culture of stromal vascular fraction from adipose tissue in methylcellulose [105]. The importance of the synergistic effect of shear and growth factors/culture medium such as VEGF, endothelial cell growth supplement, and endothelial growth media-2 in inducing the expression of some endothelial markers was demonstrated. While the acquired phenotype varied among the tested sources, also differently 
stimulated, a common feature was the nonhomogeneous character of each one of the obtained populations regarding the expression of endothelial-related markers. Furthermore, the expression of important markers, such as endothelial nitric oxide synthases, or von Willebrand factor, was either not assessed [63] or absent [95], which might significantly compromise the in vivo performance and functionality of SC-derived endothelial-like cells.

Additionally, the effect of differentiation signals provided by ECM produced by endothelial cells as well of MSC alteration of these signals over MSC endothelial differentiation was evidenced by Lozito et al. [106]. It was also demonstrated that the BM-derived MSCs cultured in the ECM produced by macrovascular endothelial cells, eliminated by cell lysis, differentiate into endothelial cells supposedly by the action of some factors provided by the matrix, including VEGF, platelet derived growth factor (PDGF), and fibroblast growth factor (FGF) as previously identified [103], showing evidence of a feedback system in which MSCs are able to alter the very matrix signals acting upon them, releasing ECdifferentiation factors from the matrix. Furthermore, the influence of the combination of growth factors, cocktail administration, and 3D polymer scaffold environment has also been highlighted in cell differentiation, namely in the formation of a 3D vessel-like network in vivo [100].

Overall, the endothelial-generated cells (see Table 2) depicted an endothelial phenotype in vitro, as proved by the typical markers; however, in vivo functionality assessment has only been demonstrated for some of the differentiation strategies [61,64,65,95,100,102,105]. A significant explanation for this might be the low yield of cells; as most strategies do not accomplish the full population differentiation, selection methodologies have been used to achieve homogeneous cultures, consequently with lower numbers. Improved culture methodologies are needed to overcome this issue and to allow the validation of the results by proving the vascular performance and integration of the differentiated cells in vivo.

\section{Stem Cells Impact in Would Healing}

Wound healing in postnatal human skin is one of the most complex biological processes. It involves a highly coordinated interplay among cells, soluble factors, and extracellular matrix, aiming at an effective wound closure [107]. The purpose of skin wound healing comprehends skin restoration and reestablishment of its tensile strength and natural barrier function [108]. Dysfunctional healing leads quite frequently to lifelong disability, having significant consequences and economic impact.

\section{Wound healing repair versus regeneration}

The distinction between repair and regeneration is crucial to understanding desirable wound healing progression, as elucidated in Fig. 3. Wound repair commonly refers to the physiological adaptation of an organ after injury, in an effort to reestablish continuity without considering the functional replacement of damaged tissue, whereas accurate tissue regeneration comprehends replacement of damaged tissue as an exact copy, in which both morphology and functionality are completely restored [109].

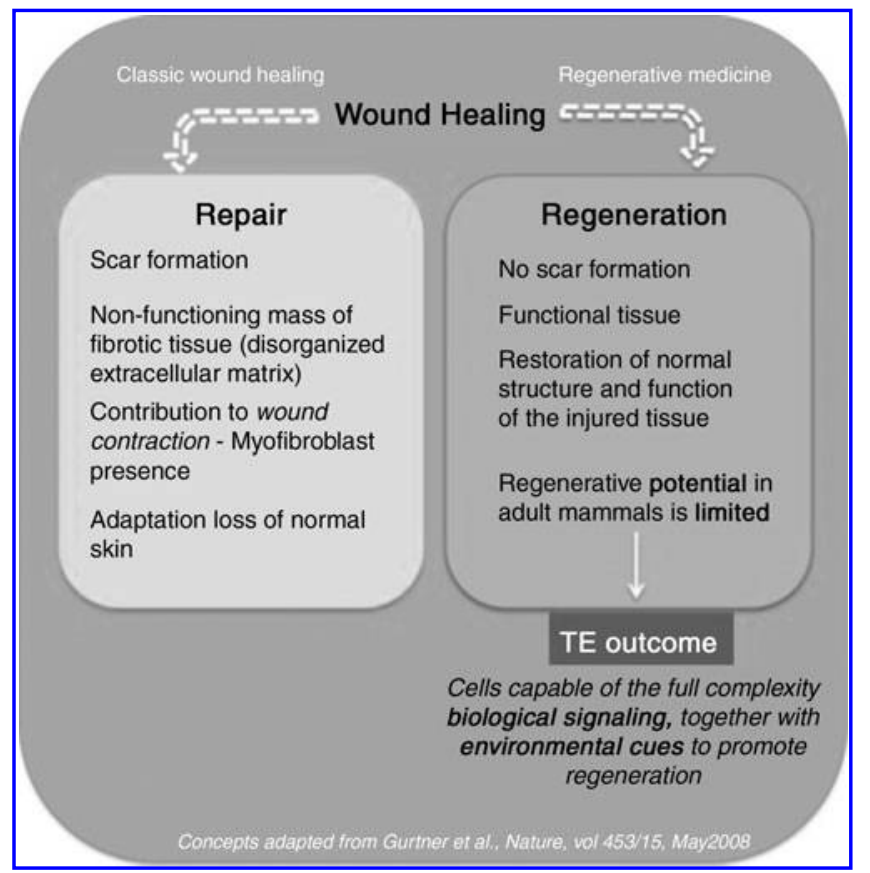

FIG. 3. Schematic overview of wound healing, focused on the major events that distinguish repair and regeneration.

In adult skin, wound-healing responses can be physiological or regenerative, respectively leading to wound repair and wound regeneration. Although the understanding of how fetal skin shifts from a regenerative response in utero to a reparative response postnatally is still in its infancy [107], it might be the key for defining how adult skin healing may be redirected to the regenerative pathway instead of the wound repair-scar formation pathway.

\section{Stem cells action}

Stem cells, besides their plasticity and self-renewal capability, are known to enhance wound healing and reduce inflammation [110]. Although the extent of stem cell involvement in cutaneous wound healing is complex and not fully understood, these cells play a significant role in promoting wound vascularization, reducing wound contraction, attenuating scar formation, and inducing keratinization, and thus in better skin healing [111]. In fact, resident stem cells from epidermis and dermis are thought to promote reepithelialization, vascularization, and extracellular matrix remodeling through paracrine communication with resident, inflammatory, or antigen presenting cells and by transdifferentiation [112,113]. A strong example of this is the innermost role of EpSCs, not only in reepithialization [114], but also in the differentiation along adnexal lines [115], thus providing a superior source of multipotent stem cells to bioengineer sebaceous glands, along with formation of hair follicles [116,117].

Paracrine signaling and interactions. Paracrine interactions designate neighboring cellular communications. Stem cells are able to interact with their microenvironment, releasing multiple wound healing factors that present several advantages when compared with administered factors [118]. Additionally, MSC paracrine signaling regulates the local 
cellular responses to injury [119]. During cutaneous healing, recruited and resident stem cells are sensitive to the disruption of this microenvironment and thus respond accordingly. Although the mechanism and the signaling pathways responsible for MSC homing to wounded and uninjured skin are not fully understood, they probably involve the complex interplay of adhesion molecules, cytokines, extracellular matrix proteases, and tissue inhibitors of matrix metalloproteinase, forming a sophisticated signaling cascade [120].

There is increasing evidence [110,121-123] that leads to the conclusion that MSC signaling is the main mechanism responsible for enhancing wound regeneration. It is thought that extensive skin injury, after the local stem cells response [124], promotes the early trafficking to the wounded region of a unique subclass of cells from bone marrow. These are the circulating bone marrow-derived cells, which include fibrocytes $[125,126]$ that originate the myofibroblast population, essential to the wound closure [127]. Injected BMderived MSCs also release IGF-1, EGF, and KGF that promote the proliferation of keratinocytes [110], and proangiogenic cytokines such as VEGF-a and angiopoietin (Ang)-1, which trigger an angiogenic response by local cells [123]. hASCs transplanted into a full-thickness skin defect have also been shown to enhance vascular density through paracrine mechanisms, along with an autocrine loop functioning, since, as suggested by the authors, local ASCs are likely to produce angiogenic factors that act on themselves or neighboring ASCs to reestablish vascularization at the wound site [128]. Interestingly, MSC-conditioned medium (MSC-CM), not only from bone marrow, but also from hASCs, appears to accelerate epithelialization, in a similar manner to what was observed when MSCs were transplanted [121,122]. BM-MSC$\mathrm{CM}$ has also been implicated in the enhancement of wound neovascularization, by exerting potent chemoattractive and mitogenic effects that lead to increasing numbers of positive cells for CD34, C-kit, or Flk-1, thus suggesting recruitment of endothelial and endothelial progenitor cells into the wound [129].

The understanding of the effect of paracrine signaling on individual cell types, envisioning to disclosure the complexity in wound site interactions, has been addressed with in vitro studies. Meeting conclusions from in vivo data, BM-MSC-CM was shown to act as a chemoattractant for macrophages and endothelial cells. [119] Also, it has been demonstrated that BM-MSCs and BM-MSC-CM are effective chemoattractants for keratinocytes and dermal fibroblasts, proving its importance in the recruitment of these two types of resident cells [130] Furthermore, MSC-CM stimulates their proliferation, along with endothelial cells, through secreted mitogenic factors [121,130,131].

Transdifferentiation. MSCs have the ability to differentiate into cell types other than mesenchymal cell lineages $[69,72,132]$, including into tissue-specific cells, as a response to cues provided by the specific niche of different organs $[39,118,133]$. This transdifferentiation phenomenon has been observed in skin wound regeneration in which MSCs gave rise to critical skin-related cell lineages such as epidermal, endothelial, and pericytic [69,72 128,132,134-136]. This was particularly detected when GFP transgenic mice BM-MSCs and hASCs seeded in silk-fibroin-chitosan scaffolds were respectively injected and transplanted into full-thickness mice skin wounds [128]. Moreover, labeled UCBSCs applied locally at the wound margin of cutaneous mice wounds were not only found to accelerate the speed of wound healing but also to transdifferentiate into keratinocytes, identified in the newly formed epidermis $[69,71,72,136]$. Yet, another study shows that BM naturally contributes to a significant percentage of dermal fibroblasts in the skin, mainly associated with hair follicles, but rarely to the newly formed epidermis [113].

Despite all those indications, it is still controversial whether MSCs significantly contribute to wound healing via transdifferentiation [132,137]; this uncertainty might be explained by the requisite of a suitable microenvironment that not only promotes specific transdifferentiation, but also sustains the viability of the transplanted cells, promoting the formation of whole biologically functional tissue. Another explanation for stem cell plasticity resides in the cell fusion phenomenon. [138,139] Unlike what frequently occurred ex vivo [140], there is evidence that fusion might not be the primary mechanism [141], and transdifferentiation is believed to be the predominant event in vivo [110]. Nonetheless, the phenomenon of cell fusion occurrence, versus direct differentiation, in stem cell therapy is not fully understood and the debate persists.

\section{Clinical Trials and Stem Cells Contribution to Wound Healing}

Several in vivo studies [142-145] have highlighted the potential of stem cells to treat skin wounds by accelerating wound healing where other methods failed before, making the statement as a strong therapeutic alternative and raising advances towards clinical trials. This data collection motivated the arising of MSC-based therapies for treating skin tissue wounds, which is reflected by the 90 clinical trials currently listed in the United States National Institutes of Health registry [120]. Despite this enormous number of clinical trials currently ongoing, only a set of studies that represent the potential of distinct adult stem cell sources on the treatment of several range of skin wounds categories will be herein discussed.

Recent studies have reinforced the significant impact of BM-MSCs $[146,147]$ in nonhealing wounds, as described in subsequent sections, showing their active contribution to wound closure, reepithelialization (by differentiating into keratinocytes), neovascularization, and appendages regeneration [110].

A major advance in the treatment of a chronic nonhealing wound (diabetic ulcer) has been made [148] using the patient's BM-MSCs in combination with autologous skin fibroblasts on biodegradable collagen membrane (Coladerm ${ }^{\circledR}$ ). Wounds showed a steady overall decrease in size and an increased dermal vascularization and thickening of the wound bed along the treatment. Furthermore, a clinical trial with a BM-MSC CD90 enriched population was also undertaken in diabetic patients with critical limb ischemia [147]. Cells were administered intramuscularly or intra-arterially, leading to revascularization of the affected limb and local perfusion enhancement, demonstrating once more the relevant role of these cells in critical wound regeneration.

On another perspective, the potential of the EpSCs isolated from hair follicle to improve wound healing in fullthickness burn patients is also being explored in clinical trials 
following different approaches. In one strategy, hair follicles were implanted in the commercial available dermal substitute Integra $^{\mathrm{TM}}$ [149] with a novel technique of micrografting that resulted in complete reepithelialization and a hairbearing scalp without the need for a split-thickness skin graft. Another approach, in phase II clinical studies, uses fully differentiated autologous epidermal equivalent derived from keratinocytes/ EpSCs of the outer root sheath of plucked anagenic hair follicles to demonstrate the effectiveness of this split-thickness skin autograft in promoting healing and complete closure of recalcitrant vascular leg ulcers [150].

Other clinical trials currently underway make use of other sources of stem cells, such as autologous lipoaspirate [151] and umbilical cord [152], to obtain MSCs respectively to treat diabetic ulcers and diabetic foot condition, reflecting the rapid emergent technology that desperately needs to move forward to meet patient needs in skin regeneration.

\section{Concluding Remarks and Perspectives}

Stem cells function as the human body's building blocks that have to make "choices." Numerous studies have begun to disclose their inner unlimited capacities, and unlike what was previously thought, they can be driven toward transdifferentiation and give rise to unexpected relevant cell lineages. Furthermore, stem cells have unique features that translate into the release of important growth factors that play decisive roles in therapeutic regenerative medicine approaches

Specifically in skin regeneration, the use of stem cells can contribute in an active way to revolutionize and overcome some of the limitations of the current approaches. Different methods have been designed and made progress in this field (eg, in the healing of chronic wounds). Stem cells, as part of skin TE constructs, interact with the resident cells providing the cues for the regeneration of a functional tissue, instead of fibrotic scar tissue. The strategies are limitless but can contemplate distinct concerns like in vitro differentiation or in vivo paracrine signaling control in different skin wound models. Either way, communication with the resident cell or even by autocrine signaling seems to be a common feature that triggers the whole therapeutic potential and takes advantage of the irreplaceable plasticity of stem cells. Thus, cellsignaling cascades seem to be the key for transplanted stem cells to efficiently engraft and subsequently to differentiate.

Beyond all the excitement in the stem cell field, technical and scientific obstacles should not be ignored, and the awareness that there are issues still to be addressed is extremely important when moving to clinical applications. In skin regeneration itself, stem cell therapeutic potential is a work in progress, where details of stem cell biology should always be present, and where the potential of off-the-shelf stem cell-based tissue engineered products is only just beginning to be realized. The great outcome of innovative stem cell-based models is opening a new era of skin regeneration, where achieving functional skin is the main concern, including the building of yet lacking appendages, such as nerves, sweat glands, and blood supply.

\section{Acknowledgments}

The authors express their gratitude to Stephen Minger for the collaboration with former Stem Cell Biology Laboratory,
King's College London, where experiments illustrated in Figs. 1 and 2 were performed, and also to Tírcia Santos for the discussion of wound healing-related concepts.

\section{Author Disclosure Statement}

No competing financial interests exist.

\section{References}

1. Priya SG, H Jungvid and A Kumar. (2008). Skin tissue engineering for tissue repair and regeneration. Tissue Eng Part B Rev 14:105-118.

2. MacNeil S. (2007). Progress and opportunities for tissueengineered skin. Nature 445:874-880.

3. Mansbridge JN. (2009). Tissue-engineered skin substitutes in regenerative medicine. Curr Opin Biotechnol 20: 563-567.

4. Bello YM and AF Falabella. (2002). The role of graftskin (Apligraf) in difficult-to-heal venous leg ulcers. J Wound Care 11:182-183.

5. Sahota PS, JL Burn, M Heaton, E Freedlander, SK Suvarna, NJ Brown and S Mac Neil. (2003). Development of a reconstructed human skin model for angiogenesis. Wound Repair Regen 11:275-284.

6. Black AF, F Berthod, N L'Heureux, L Germain and FA Auger. (1998). In vitro reconstruction of a human capillarylike network in a tissue-engineered skin equivalent. FASEB J 12:1331-1340.

7. Tremblay PL, V Hudon, F Berthod, L Germain and FA Auger. (2005). Inosculation of tissue-engineered capillaries with the host's vasculature in a reconstructed skin transplanted on mice. Am J Transplant 5:1002-1010.

8. Tonello C, V Vindigni, B Zavan, S Abatangelo, G Abatangelo, P Brun and R Cortivo. (2005). In vitro reconstruction of an endothelialized skin substitute provided with a microcapillary network using biopolymer scaffolds. FASEB I 19:1546-1548.

9. Aberdam D, K Gambaro, P Rostagno, E Aberdam, S de la Forest Divonne and M Rouleau. (2007). Key role of p63 in BMP-4-induced epidermal commitment of embryonic stem cells. Cell Cycle 6:291-294.

10. Sahota PS, JL Burn, NJ Brown and S MacNeil. (2004). Approaches to improve angiogenesis in tissue-engineered skin. Wound Repair Regen 12:635-642.

11. Kearney JN. (2001). Clinical evaluation of skin substitutes. Burns 27:545-551.

12. Barrandon Y and H Green. (1987). Three clonal types of keratinocyte with different capacities for multiplication. Proc Natl Acad Sci U S A 84:2302-2306.

13. Mimeault M and SK Batra. (2008). Recent progress on tissue-resident adult stem cell biology and their therapeutic implications. Stem Cell Rev 4:27-49.

14. Verfaillie C. (2005). Stem cell plasticity. Hematology 10 Suppl 1:293-296.

15. Mountford JC. (2008). Human embryonic stem cells: origins, characteristics and potential for regenerative therapy. Transfus Med 18:1-12.

16. Leeper NJ, AL Hunter and JP Cooke. (2009). Stem cell therapy for vascular regeneration: adult, embryonic, and induced pluripotent stem cells. Circulation 122:517-526.

17. Brignier AC and AM Gewirtz. (2010). Embryonic and adult stem cell therapy. J Allergy Clin Immunol 125:S336-344.

18. Trottier V, G Marceau-Fortier, L Germain, C Vincent and J Fradette. (2008). IFATS collection: Using human 
adipose-derived stem/stromal cells for the production of new skin substitutes. Stem Cells 26:2713-2723.

19. Riekstina U, I Cakstina, V Parfejevs, M Hoogduijn, G Jankovskis, I Muiznieks, R Muceniece and J Ancans. (2009). Embryonic stem cell marker expression pattern in human mesenchymal stem cells derived from bone marrow, adipose tissue, heart and dermis. Stem Cell Rev 5:378-386.

20. Koc ON, J Day, M Nieder, SL Gerson, HM Lazarus and W Krivit. (2002). Allogeneic mesenchymal stem cell infusion for treatment of metachromatic leukodystrophy (MLD) and Hurler syndrome (MPS-IH). Bone Marrow Transplant 30:215-222.

21. Kemp KC, J Hows and C Donaldson. (2005). Bone marrowderived mesenchymal stem cells. Leuk Lymphoma 46: 1531-1544.

22. Zuk PA, M Zhu, H Mizuno, J Huang, JW Futrell, AJ Katz, P Benhaim, HP Lorenz and MH Hedrick. (2001). Multilineage cells from human adipose tissue: implications for cell-based therapies. Tissue Eng 7:211-228.

23. Kim J, Y Lee, H Kim, KJ Hwang, HC Kwon, SK Kim, DJ Cho, SG Kang and J You. (2007). Human amniotic fluidderived stem cells have characteristics of multipotent stem cells. Cell Prolif 40:75-90.

24. De Coppi P, G Bartsch, Jr., MM Siddiqui, T Xu, CC Santos, L Perin, G Mostoslavsky, AC Serre, EY Snyder, et al. (2007). Isolation of amniotic stem cell lines with potential for therapy. Nat Biotechnol 25:100-106.

25. Bieback K, S Kern, H Kluter and H Eichler. (2004). Critical parameters for the isolation of mesenchymal stem cells from umbilical cord blood. Stem Cells 22:625-634.

26. Baal N, K Reisinger, H Jahr, RM Bohle, O Liang, K Munstedt, CV Rao, KT Preissner and MT Zygmunt. (2004). Expression of transcription factor Oct-4 and other embryonic genes in CD133 positive cells from human umbilical cord blood. Thromb Haemost 92:767-775.

27. Bartsch G, JJ Yoo, P De Coppi, MM Siddiqui, G Schuch, HG Pohl, J Fuhr, L Perin, S Soker and A Atala. (2005). Propagation, expansion, and multilineage differentiation of human somatic stem cells from dermal progenitors. Stem Cells Dev 14:337-348.

28. Sellheyer K and D Krahl. (2010). Skin mesenchymal stem cells: prospects for clinical dermatology. I Am Acad Dermatol 63:859-865.

29. Lazarus HM, SE Haynesworth, SL Gerson, NS Rosenthal and AI Caplan. (1995). Ex vivo expansion and subsequent infusion of human bone marrow-derived stromal progenitor cells (mesenchymal progenitor cells): implications for therapeutic use. Bone Marrow Transplant 16:557-564.

30. Corselli M, CW Chen, M Crisan, L Lazzari and B Peault. (2010). Perivascular ancestors of adult multipotent stem cells. Arterioscler Thromb Vasc Biol 30:1104-1109.

31. Feng J, A Mantesso, C De Bari, A Nishiyama and PT Sharpe. (2011). Dual origin of mesenchymal stem cells contributing to organ growth and repair. Proc Natl Acad Sci U S A 108:6503-6508.

32. da Silva Meirelles L, AI Caplan and NB Nardi. (2008). In search of the in vivo identity of mesenchymal stem cells. Stem Cells 26:2287-2299.

33. Crisan M, S Yap, L Casteilla, CW Chen, M Corselli, TS Park, G Andriolo, B Sun, B Zheng, et al. (2008). A perivascular origin for mesenchymal stem cells in multiple human organs. Cell Stem Cell 3:301-313.

34. Lorenz K, M Sicker, E Schmelzer, T Rupf, J Salvetter, M Schulz-Siegmund and A Bader. (2008). Multilineage dif- ferentiation potential of human dermal skin-derived fibroblasts. Exp Dermatol 17:925-932.

35. Haniffa MA, XN Wang, U Holtick, M Rae, JD Isaacs, AM Dickinson, CM Hilkens and MP Collin. (2007). Adult human fibroblasts are potent immunoregulatory cells and functionally equivalent to mesenchymal stem cells. I Immunol 179:1595-1604.

36. Haniffa MA, MP Collin, CD Buckley and F Dazzi. (2009). Mesenchymal stem cells: the fibroblasts' new clothes? Haematologica 94:258-263.

37. Blanpain C and E Fuchs. (2006). Epidermal stem cells of the skin. Annu Rev Cell Dev Biol 22:339-373.

38. Cotsarelis G. (2006). Epithelial stem cells: a folliculocentric view. J Invest Dermatol 126:1459-1468.

39. Fernandes KJ, IA McKenzie, P Mill, KM Smith, M Akhavan, F Barnabe-Heider, J Biernaskie, A Junek, NR Kobayashi, et al. (2004). A dermal niche for multipotent adult skin-derived precursor cells. Nat Cell Biol 6:1082-1093.

40. Alonso L and E Fuchs. (2003). Stem cells of the skin epithelium. Proc Natl Acad Sci U S A 100 Suppl 1:1183011835.

41. Jones PH and FM Watt. (1993). Separation of human epidermal stem cells from transit amplifying cells on the basis of differences in integrin function and expression. Cell 73:713-724.

42. Watt FM. (1998). Epidermal stem cells: markers, patterning and the control of stem cell fate. Philos Trans R Soc Lond B Biol Sci 353:831-837.

43. Li A, PJ Simmons and P Kaur. (1998). Identification and isolation of candidate human keratinocyte stem cells based on cell surface phenotype. Proc Natl Acad Sci U S A 95:3902-3907.

44. Kaur P and A Li. (2000). Adhesive properties of human basal epidermal cells: an analysis of keratinocyte stem cells, transit amplifying cells, and postmitotic differentiating cells. J Invest Dermatol 114:413-420.

45. Jaks V, N Barker, M Kasper, JH van Es, HJ Snippert, H Clevers and R Toftgard. (2008). Lgr5 marks cycling, yet long-lived, hair follicle stem cells. Nat Genet 40:1291-1299.

46. Snippert HJ, A Haegebarth, M Kasper, V Jaks, JH van Es, N Barker, $M$ van de Wetering, $M$ van den Born, $\mathrm{H}$ Begthel, et al. (2010). Lgr6 marks stem cells in the hair follicle that generate all cell lineages of the skin. Science 327: 1385-1389.

47. Lane EB, CA Wilson, BR Hughes and IM Leigh. (1991). Stem cells in hair follicles. Cytoskeletal studies. Ann N Y Acad Sci 642:197-213.

48. Pontiggia L, T Biedermann, M Meuli, D Widmer, S Bottcher-Haberzeth, C Schiestl, J Schneider, E Braziulis, I Montano, C Meuli-Simmen and E Reichmann. (2009). Markers to evaluate the quality and self-renewing potential of engineered human skin substitutes in vitro and after transplantation. J Invest Dermatol 129:480-490.

49. Watt FM, C Lo Celso and V Silva-Vargas. (2006). Epidermal stem cells: an update. Curr Opin Genet Dev 16:518-524.

50. Gharzi A, AJ Reynolds and CA Jahoda. (2003). Plasticity of hair follicle dermal cells in wound healing and induction. Exp Dermatol 12:126-136.

51. Toma JG, IA McKenzie, D Bagli and FD Miller. (2005). Isolation and characterization of multipotent skin-derived precursors from human skin. Stem Cells 23:727-737.

52. Jahoda CA and AJ Reynolds. (2001). Hair follicle dermal sheath cells: unsung participants in wound healing. Lancet 358:1445-1448. 
53. Hunt DP, C Jahoda and S Chandran. (2009). Multipotent skin-derived precursors: from biology to clinical translation. Curr Opin Biotechnol 20:522-530.

54. Stojkovic M, M Lako, P Stojkovic, R Stewart, S Przyborski, L Armstrong, J Evans, M Herbert, L Hyslop, et al. (2004). Derivation of human embryonic stem cells from day-8 blastocysts recovered after three-step in vitro culture. Stem Cells 22:790-797.

55. Metallo CM, SM Azarin, L Ji, JJ de Pablo and SP Palecek. (2008). Engineering tissue from human embryonic stem cells. J Cell Mol Med 12:709-729.

56. Metallo CM, L Ji, JJ de Pablo and SP Palecek. (2008). Retinoic acid and bone morphogenetic protein signaling synergize to efficiently direct epithelial differentiation of human embryonic stem cells. Stem Cells 26:372-380.

57. Guenou H, X Nissan, F Larcher, J Feteira, G Lemaitre, M Saidani, M Del Rio, CC Barrault, FX Bernard, et al. (2009). Human embryonic stem-cell derivatives for full reconstruction of the pluristratified epidermis: a preclinical study. Lancet 374:1745-1753.

58. Aberdam D. (2004). Derivation of keratinocyte progenitor cells and skin formation from embryonic stem cells. Int J Dev Biol 48:203-206.

59. Aberdam D, K Gambaro, A Medawar, E Aberdam, P Rostagno, S de la Forest Divonne and M Rouleau. (2007). Embryonic stem cells as a cellular model for neuroectodermal commitment and skin formation. C R Biol 330:479484.

60. Metallo CM, SM Azarin, LE Moses, L Ji, JJ de Pablo and SP Palecek. (2010). Human embryonic stem cell-derived keratinocytes exhibit an epidermal transcription program and undergo epithelial morphogenesis in engineered tissue constructs. Tissue Eng Part A 16:213-223.

61. Levenberg S, JS Golub, M Amit, J Itskovitz-Eldor and R Langer. (2002). Endothelial cells derived from human embryonic stem cells. Proc Natl Acad Sci U S A 99:4391-4396.

62. Levenberg S, J Zoldan, Y Basevitch and R Langer. (2007). Endothelial potential of human embryonic stem cells. Blood 110:806-814.

63. Bai K, Y Huang, X Jia, Y Fan and W Wang. (2009). Endothelium oriented differentiation of bone marrow mesenchymal stem cells under chemical and mechanical stimulations. J Biomech 43:1176-1181.

64. Nakahara M, N Nakamura, S Matsuyama, Y Yogiashi, K Yasuda, Y Kondo, A Yuo and K Saeki. (2009). High-efficiency production of subculturable vascular endothelial cells from feeder-free human embryonic stem cells without cell-sorting technique. Cloning Stem Cells 11:509-522.

65. Gerecht-Nir S, JE Dazard, M Golan-Mashiach, S Osenberg, A Botvinnik, N Amariglio, E Domany, G Rechavi, D Givol and J Itskovitz-Eldor. (2005). Vascular gene expression and phenotypic correlation during differentiation of human embryonic stem cells. Dev Dyn 232:487-497.

66. Wang L, L Li, F Shojaei, K Levac, C Cerdan, P Menendez, T Martin, A Rouleau and M Bhatia. (2004). Endothelial and hematopoietic cell fate of human embryonic stem cells originates from primitive endothelium with hemangioblastic properties. Immunity 21:31-41.

67. Chen M, M Przyborowski and F Berthiaume. (2009). Stem cells for skin tissue engineering and wound healing. Crit Rev Biomed Eng 37:399-421.

68. Tran CT, DT Huynh, C Gargiulo, PT Nguyen, TT Tran, MT Huynh, TT Nguyen, L Filgueira and DM Strong. (2010). In vitro culture of Keratinocytes from human umbilical cord blood mesenchymal stem cells: the Saigonese culture. Cell Tissue Bank 12:125-133.

69. Chun-mao H, W Su-yi, L Ping-ping and C Hang-hui. (2007). Human bone marrow-derived mesenchymal stem cells differentiate into epidermal-like cells in vitro. Differentiation 75:292-298.

70. Hong J, J Lee, KH Min, JR Walker, EC Peters, NS Gray, CY Cho and PG Schultz. (2007). Identification and characterization of small-molecule inducers of epidermal keratinocyte differentiation. ACS Chem Biol 2:171-175.

71. Kamolz LP, A Kolbus, N Wick, PR Mazal, B Eisenbock, S Burjak and G Meissl. (2006). Cultured human epithelium: human umbilical cord blood stem cells differentiate into keratinocytes under in vitro conditions. Burns 32:16-19.

72. Paunescu V, E Deak, D Herman, IR Siska, G Tanasie, C Bunu, S Anghel, CA Tatu, TI Oprea, et al. (2007). In vitro differentiation of human mesenchymal stem cells to epithelial lineage. I Cell Mol Med 11:502-508.

73. Brzoska M, H Geiger, S Gauer and P Baer. (2005). Epithelial differentiation of human adipose tissue-derived adult stem cells. Biochem Biophys Res Commun 330:142-150.

74. Green H, K Easley and S Iuchi. (2003). Marker succession during the development of keratinocytes from cultured human embryonic stem cells. Proc Natl Acad Sci U S A 100:15625-15630.

75. Aberdam E, E Barak, M Rouleau, S de LaForest, S BerrihAknin, DM Suter, KH Krause, M Amit, J Itskovitz-Eldor and D Aberdam. (2008). A pure population of ectodermal cells derived from human embryonic stem cells. Stem Cells 26:440-444.

76. Alexanian AR, CN Svendsen, MJ Crowe and SN Kurpad. (2010). Transplantation of human glial-restricted neural precursors into injured spinal cord promotes functional and sensory recovery without causing allodynia. Cytotherapy 13:61-68.

77. Singh AB and RC Harris. (2005). Autocrine, paracrine and juxtacrine signaling by EGFR ligands. Cell Signal 17:11831193.

78. Huang L, YP Wong, H Gu, YJ Cai, Y Ho, CC Wang, TY Leung and A Burd. (2010). Stem cell-like properties of human umbilical cord lining epithelial cells and the potential for epidermal reconstitution. Cytotherapy 13:145-155.

79. Schuldiner $\mathrm{M}, \mathrm{O}$ Yanuka, J Itskovitz-Eldor, DA Melton and N Benvenisty. (2000). Effects of eight growth factors on the differentiation of cells derived from human embryonic stem cells. Proc Natl Acad Sci U S A 97:11307-11312.

80. Iuchi S, S Dabelsteen, K Easley, JG Rheinwald and H Green. (2006). Immortalized keratinocyte lines derived from human embryonic stem cells. Proc Natl Acad Sci U S A 103:1792-1797.

81. Aberdam D. (2008). Epidermal stem cell fate: what can we learn from embryonic stem cells? Cell Tissue Res 331:103107.

82. Sengel P. Morphogenesis of Skin. (1976). Cambridge University Press. Cambridge, UK; New York.

83. Coraux C, C Hilmi, M Rouleau, A Spadafora, J Hinnrasky, JP Ortonne, C Dani and D Aberdam. (2003). Reconstituted skin from murine embryonic stem cells. Curr Biol 13:849853.

84. Munoz-Sanjuan I and AH Brivanlou. (2002). Neural induction, the default model and embryonic stem cells. Nat Rev Neurosci 3:271-280.

85. Laurikkala J, ML Mikkola, M James, M Tummers, AA Mills and I Thesleff. (2006). p63 regulates multiple signalling 
pathways required for ectodermal organogenesis and differentiation. Development 133:1553-1563.

86. Romano RA, B Birkaya and S Sinha. (2007). A functional enhancer of keratin14 is a direct transcriptional target of deltaNp63. I Invest Dermatol 127:1175-1186.

87. Gambaro K, E Aberdam, T Virolle, D Aberdam and M Rouleau. (2006). BMP-4 induces a Smad-dependent apoptotic cell death of mouse embryonic stem cell-derived neural precursors. Cell Death Differ 13:1075-1087.

88. Troy TC and K Turksen. (2006). Directing epidermal fate selection by a novel co-culture system. Methods Mol Biol 330:105-111.

89. Broughton G, 2nd, JE Janis and CE Attinger. (2006). The basic science of wound healing. Plast Reconstr Surg 117:12S-34S.

90. Kane NM, Q Xiao, AH Baker, Z Luo, Q Xu and C Emanueli. (2011). Pluripotent stem cell differentiation into vascular cells: a novel technology with promises for vascular re(generation). Pharmacol Ther 129:29-49.

91. Levenberg S. (2005). Engineering blood vessels from stem cells: recent advances and applications. Curr Opin Biotechnol 16:516-523.

92. Chen MY, PC Lie, ZL Li and X Wei. (2009). Endothelial differentiation of Wharton's jelly-derived mesenchymal stem cells in comparison with bone marrow-derived mesenchymal stem cells. Exp Hematol 37:629-640.

93. Oswald J, S Boxberger, B Jorgensen, S Feldmann, G Ehninger, M Bornhauser and C Werner. (2004). Mesenchymal stem cells can be differentiated into endothelial cells in vitro. Stem Cells 22:377-384.

94. Yu-Jia D, C Jia, Z Hong-Gang, Z Jing, Z Qiu-Ju and X Rui-Juan. (2011). In vitro effect of $\mathrm{N}$-(6-aminohexyl)-5chloro-1-naphthalenesulfonamide on differentiation from human adipose-derived mesenchymal stem cells to endothelial cells. Zhongguo Yi Xue Ke Xue Yuan Xue Bao 33:306-312.

95. Fischer LJ, S McIlhenny, T Tulenko, N Golesorkhi, P Zhang, R Larson, J Lombardi, I Shapiro and PJ DiMuzio. (2009). Endothelial differentiation of adipose-derived stem cells: effects of endothelial cell growth supplement and shear force. J Surg Res 152:157-166.

96. Zhang P, J Baxter, K Vinod, TN Tulenko and PJ Di Muzio. (2009). Endothelial differentiation of amniotic fluid-derived stem cells: synergism of biochemical and shear force stimuli. Stem Cells Dev 18:1299-1308.

97. Gang EJ, JA Jeong, S Han, Q Yan, CJ Jeon and H Kim. (2006). In vitro endothelial potential of human UC bloodderived mesenchymal stem cells. Cytotherapy 8:215-227.

98. Woll PS, JK Morris, MS Painschab, RK Marcus, AD Kohn, TL Biechele, RT Moon and DS Kaufman. (2008). Wnt signaling promotes hematoendothelial cell development from human embryonic stem cells. Blood 111:122-131.

99. Hill KL, P Obrtlikova, DF Alvarez, JA King, SA Keirstead, JR Allred and DS Kaufman. (2010). Human embryonic stem cell-derived vascular progenitor cells capable of endothelial and smooth muscle cell function. Exp Hematol 38:246-257 e241.

100. Levenberg S, NF Huang, E Lavik, AB Rogers, J ItskovitzEldor and R Langer. (2003). Differentiation of human embryonic stem cells on three-dimensional polymer scaffolds. Proc Natl Acad Sci U S A 100:12741-12746.

101. Reilly GC and AJ Engler. (2010). Intrinsic extracellular matrix properties regulate stem cell differentiation. J Biomech 43:55-62.
102. Zhang G, CT Drinnan, LR Geuss and LJ Suggs. (2010). Vascular differentiation of bone marrow stem cells is directed by a tunable three-dimensional matrix. Acta Biomater 6:3395-3403.

103. Kalluri R. (2003). Basement membranes: structure, assembly and role in tumour angiogenesis. Nat Rev Cancer 3:422-433.

104. Vater C, P Kasten and M Stiehler. (2011). Culture media for the differentiation of mesenchymal stromal cells. Acta Biomater 7:463-477.

105. Planat-Benard V, JS Silvestre, B Cousin, M Andre, M Nibbelink, R Tamarat, M Clergue, C Manneville, C SaillanBarreau, M Duriez, A Tedgui, B Levy, L Penicaud and L Casteilla. (2004). Plasticity of human adipose lineage cells toward endothelial cells: physiological and therapeutic perspectives. Circulation 109:656-663.

106. Lozito TP, JM Taboas, CK Kuo and RS Tuan. (2009). Mesenchymal stem cell modification of endothelial matrix regulates their vascular differentiation. J Cell Biochem 107:706-713.

107. Orgill D and C Blanco. Biomaterials for Treating Skin Loss. (2009). Woodhead Publishing Limited. Cambridge, UK.

108. Singer AJ, HC Thode, Jr. and SA McClain. (2000). Development of a histomorphologic scale to quantify cutaneous scars after burns. Acad Emerg Med 7:1083-1088.

109. Yannas IV. Tissue and Organ Regeneration in Adults. (2001). Springer Verlag, New York.

110. Wu Y, L Chen, PG Scott and EE Tredget. (2007). Mesenchymal stem cells enhance wound healing through differentiation and angiogenesis. Stem Cells 25:2648-2659.

111. Liu P, Z Deng, S Han, T Liu, N Wen, W Lu, X Geng, S Huang and $Y$ Jin. (2008). Tissue-engineered skin containing mesenchymal stem cells improves burn wounds. Artif Organs 32:925-931.

112. Jeon YK, YH Jang, DR Yoo, SN Kim, SK Lee and MJ Nam. (2010). Mesenchymal stem cells' interaction with skin: wound-healing effect on fibroblast cells and skin tissue. Wound Repair Regen 18:655-661.

113. Fathke C, L Wilson, J Hutter, V Kapoor, A Smith, A Hocking and F Isik. (2004). Contribution of bone marrowderived cells to skin: collagen deposition and wound repair. Stem Cells 22:812-822.

114. Taylor G, MS Lehrer, PJ Jensen, TT Sun and RM Lavker. (2000). Involvement of follicular stem cells in forming not only the follicle but also the epidermis. Cell 102: 451-461.

115. Blanpain C, WE Lowry, A Geoghegan, L Polak and E Fuchs. (2004). Self-renewal, multipotency, and the existence of two cell populations within an epithelial stem cell niche. Cell 118:635-648.

116. Larouche D, K Cuffley, C Paquet and L Germain. (2011). Tissue-engineered skin preserving the potential of epithelial cells to differentiate into hair after grafting. Tissue Eng Part A 17:819-830.

117. Zheng $\mathrm{Y}, \mathrm{X}$ Du, $\mathrm{W}$ Wang, $\mathrm{M}$ Boucher, $\mathrm{S}$ Parimoo and $\mathrm{K}$ Stenn. (2005). Organogenesis from dissociated cells: generation of mature cycling hair follicles from skin-derived cells. J Invest Dermatol 124:867-876.

118. Jiang Y, BN Jahagirdar, RL Reinhardt, RE Schwartz, CD Keene, XR Ortiz-Gonzalez, M Reyes, T Lenvik, T Lund, et al. (2002). Pluripotency of mesenchymal stem cells derived from adult marrow. Nature 418:41-49.

119. Chen L, EE Tredget, PY Wu and Y Wu. (2008). Paracrine factors of mesenchymal stem cells recruit macrophages and 
endothelial lineage cells and enhance wound healing. PLoS One 3:e1886.

120. Hocking AM and NS Gibran. (2010). Mesenchymal stem cells: paracrine signaling and differentiation during cutaneous wound repair. Exp Cell Res 316:2213-2219.

121. Kim WS, BS Park, JH Sung, JM Yang, SB Park, SJ Kwak and JS Park. (2007). Wound healing effect of adipose-derived stem cells: a critical role of secretory factors on human dermal fibroblasts. J Dermatol Sci 48:15-24.

122. Lee EY, Y Xia, WS Kim, MH Kim, TH Kim, KJ Kim, BS Park and JH Sung. (2009). Hypoxia-enhanced wound-healing function of adipose-derived stem cells: increase in stem cell proliferation and up-regulation of VEGF and bFGF. Wound Repair Regen 17:540-547.

123. Mayer H, H Bertram, W Lindenmaier, $T$ Korff, $H$ Weber and $\mathrm{H}$ Weich. (2005). Vascular endothelial growth factor (VEGF-A) expression in human mesenchymal stem cells: autocrine and paracrine role on osteoblastic and endothelial differentiation. J Cell Biochem 95:827-839.

124. Verstappen J, C Katsaros, R Torensma and JW Von den Hoff. (2009). A functional model for adult stem cells in epithelial tissues. Wound Repair Regen 17:296-305.

125. Abe R, SC Donnelly, T Peng, R Bucala and CN Metz. (2001). Peripheral blood fibrocytes: differentiation pathway and migration to wound sites. J Immunol 166:75567562.

126. Yang L, PG Scott, C Dodd, A Medina, H Jiao, HA Shankowsky, A Ghahary and EE Tredget. (2005). Identification of fibrocytes in postburn hypertrophic scar. Wound Repair Regen 13:398-404.

127. Mori L, A Bellini, MA Stacey, M Schmidt and S Mattoli. (2005). Fibrocytes contribute to the myofibroblast population in wounded skin and originate from the bone marrow. Exp Cell Res 304:81-90.

128. Altman AM, Y Yan, N Matthias, X Bai, C Rios, AB Mathur, YH Song and EU Alt. (2009). IFATS collection: human adipose-derived stem cells seeded on a silk fibroin-chitosan scaffold enhance wound repair in a murine soft tissue injury model. Stem Cells 27:250-258.

129. Mylotte LA, AM Duffy, M Murphy, T O'Brien, A Samali, F Barry and E Szegezdi. (2008). Metabolic flexibility permits mesenchymal stem cell survival in an ischemic environment. Stem Cells 26:1325-1336.

130. Smith AN, E Willis, VT Chan, LA Muffley, FF Isik, NS Gibran and AM Hocking. (2009). Mesenchymal stem cells induce dermal fibroblast responses to injury. Exp Cell Res 316:48-54.

131. Javazon EH, SG Keswani, AT Badillo, TM Crombleholme, PW Zoltick, AP Radu, ED Kozin, K Beggs, AA Malik and AW Flake. (2007). Enhanced epithelial gap closure and increased angiogenesis in wounds of diabetic mice treated with adult murine bone marrow stromal progenitor cells. Wound Repair Regen 15:350-359.

132. Sasaki M, R Abe, Y Fujita, S Ando, D Inokuma and H Shimizu. (2008). Mesenchymal stem cells are recruited into wounded skin and contribute to wound repair by transdifferentiation into multiple skin cell type. I Immunol 180:2581-2587.

133. Moore KA and IR Lemischka. (2006). Stem cells and their niches. Science 311:1880-1885.

134. Amos PJ, CL Mulvey, S Seaman, J Walpole, KE Degen, H Shang, AJ Katz and SM Peirce-Cottler. (2011). Hypoxic culture and in vivo inflammatory environments affect the assumption of pericyte characteristics by human adipose and bone marrow progenitor cells. Am J Physiol Cell Physiol. Volume 301 no. 6 e1378-e1388.

135. Sorrell JM, MA Baber and AI Caplan. (2009). Influence of adult mesenchymal stem cells on in vitro vascular formation. Tissue Eng Part A 15:1751-1761.

136. Luo G, W Cheng, W He, X Wang, J Tan, M Fitzgerald, X Li and J Wu. (2010). Promotion of cutaneous wound healing by local application of mesenchymal stem cells derived from human umbilical cord blood. Wound Repair Regen 18:506-513.

137. Sorrell JM and AI Caplan. (2010). Topical delivery of mesenchymal stem cells and their function in wounds. Stem Cell Res Ther 1:30.

138. Wurmser AE and FH Gage. (2002). Stem cells: cell fusion causes confusion. Nature 416:485-487.

139. Terada N, T Hamazaki, M Oka, M Hoki, DM Mastalerz, Y Nakano, EM Meyer, L Morel, BE Petersen and EW Scott. (2002). Bone marrow cells adopt the phenotype of other cells by spontaneous cell fusion. Nature 416:542-545.

140. Spees JL, SD Olson, J Ylostalo, PJ Lynch, J Smith, A Perry, A Peister, MY Wang and DJ Prockop. (2003). Differentiation, cell fusion, and nuclear fusion during ex vivo repair of epithelium by human adult stem cells from bone marrow stroma. Proc Natl Acad Sci U S A 100:2397-2402.

141. Anversa P, A Leri, M Rota, T Hosoda, C Bearzi, K Urbanek, J Kajstura and R Bolli. (2007). Concise review: stem cells, myocardial regeneration, and methodological artifacts. Stem Cells 25:589-601.

142. Yoshikawa T, H Mitsuno, I Nonaka, Y Sen, K Kawanishi, Y Inada, Y Takakura, K Okuchi and A Nonomura. (2008). Wound therapy by marrow mesenchymal cell transplantation. Plast Reconstr Surg 121:860-877.

143. Kwon DS, X Gao, YB Liu, DS Dulchavsky, AL Danyluk, M Bansal, M Chopp, K McIntosh, AS Arbab, SA Dulchavsky and SC Gautam. (2008). Treatment with bone marrow-derived stromal cells accelerates wound healing in diabetic rats. Int Wound J 5:453-463.

144. Badillo AT, RA Redden, L Zhang, EJ Doolin and KW Liechty. (2007). Treatment of diabetic wounds with fetal murine mesenchymal stromal cells enhances wound closure. Cell Tissue Res 329:301-311.

145. Stoff A, AA Rivera, N Sanjib Banerjee, ST Moore, T Michael Numnum, A Espinosa-de-Los-Monteros, DF Richter, GP Siegal, LT Chow, et al. (2009). Promotion of incisional wound repair by human mesenchymal stem cell transplantation. Exp Dermatol 18:362-369.

146. Badiavas EV, D Ford, P Liu, N Kouttab, J Morgan, A Richards and A Maizel. (2007). Long-term bone marrow culture and its clinical potential in chronic wound healing. Wound Repair Regen 15:856-865.

147. Ruhr University of Bochum. (2010). Induced Wound Healing by Application of Expanded Bone Marrow Stem Cells in Diabetic Patients With Critical Limb Ischemia. http://clinicaltrials.gov/ct2/show/NCT01065337. Clinical Trials.gov.

148. Vojtassak J, L Danisovic, M Kubes, D Bakos, L Jarabek, M Ulicna and M Blasko. (2006). Autologous biograft and mesenchymal stem cells in treatment of the diabetic foot. Neuro Endocrinol Lett 27 Suppl 2:134-137.

149. Navsaria HA, NO Ojeh, N Moiemen, MA Griffiths and JD Frame. (2004). Reepithelialization of a full-thickness burn from stem cells of hair follicles micrografted into a tissueengineered dermal template (Integra). Plast Reconstr Surg 113:978-981. 
150. Tausche AK, M Skaria, L Bohlen, K Liebold, J Hafner, H Friedlein, M Meurer, RJ Goedkoop, U Wollina, D Salomon and T Hunziker. (2003). An autologous epidermal equivalent tissue-engineered from follicular outer root sheath keratinocytes is as effective as split-thickness skin autograft in recalcitrant vascular leg ulcers. Wound Repair Regen 11:248-252.

151. Washington DC Veterans Affairs Medical Center. (2010). The Role of Lipoaspirate Injection in the Treatment of Diabetic Lower Extremity Wounds and Venous Stasis Ulcers. http://clinicaltrials.gov/ct2/show/NCT00815217. ClinicalTrials.gov.

152. Qingdao University. (2011). Umbilical Cord Mesenchymal Stem Cells Injection for Diabetic Foot. http://clinicaltrials .gov/ct2/show/NCT01216865/. ClinicalTrials.gov.
Address correspondence to: Dr. Alexandra P. Marques

Headquarters of the European Institute of Excellence on Tissue Engineering and Regenerative Medicine AvePark, Zona Industrial da Gandra

S. Cláudio do Barco 4806-909 Caldas das Taipas Guimarães Portugal

E-mail: apmarques@dep.uminho.pt

Received for publication September 20, 2011 Accepted after revision December 21, 2011 Prepublished on Liebert Instant Online XXXX XX, XXXX 